\title{
Changes in the Immunological Parameters after a Single Dose of Forphenicinol, a New Small Molecular Immunomodifier*
}

\author{
Nobuko Kumano, Yushi Nakai, Tetsuko Ishikawa, \\ Sadahiro Koinumaru, Shuji Suzuki, Kotaro Oizumi \\ and Kiyoshi Konno \\ Department of Internal Medicine, The Research Institute \\ for Tuberculosis and Cancer, Tohoku University, Sendai \\ 980
}

Kumano, N., Nakai, Y., Ishikawa, T., Koinumaru, S., Suzuki, S., Oizumi, K. and Konno, K. Changes in the Immunological Parameters after a Single Dose of Forphenicinol, a New Small Molecular Immunomodifier. Tohoku J. exp. Med., 1985, $146(4), \quad 419-427$ - Forphenicinol [L-2-(3-hydroxy-4-hydroxymethy]phenyl) glycine, M.W. 197.19] is a derivative of forphenicine, an inhibitor of alkaline phosphatase discovered by Umezawa. In order to find an optimal dose, a single dose of the drug ranging from 10 to $600 \mathrm{mg}$ per body was orally administered to a total of 55 patients ( 36 cancer, 13 tuberculosis, and 6 others). The possible changes in the percentages of the peripheral $\mathrm{T}$ and $\mathrm{B}$ lymphocytes, natural killer (NK) activity, and the proliferative response to phytohemaglutinin (PHA) were studied as immunological parameters. A significant effect of forphenicinol was demonstrated in restoring the normal proportion of $\mathrm{T}$ and $\mathrm{B}$ cells, especially in those who had 'low'- $T$ and/or 'high'-B before administration of the drug. No difference was found between cancer and tuberculosis. The mean percentage of $\mathrm{T}$ cells increased from the low initial level of 68.0 to 75.6 in cancer $(n=12, p<0.05)$ or from 63.1 to 78.5 in tuberculosis $(n=7, p<0.05)$, while that of $\mathrm{B}$ cells decreased from the high initial level of 34.6 to 26.9 in cancer $(n=7)$ or from 34.9 to 14.3 in tuberculosis $(n=6, p<0.025)$. The effect of a single dose of the drug tended to disappear by day 8 , a peak response being found on day 3 in most cases. With respect to this parameter, an optimal dose was found in a range from 60 to $100 \mathrm{mg}$. Forphenicinol was rather inhibitory on the NK activity, while it exerted diverse effect on the lymphocyte proliferation. No evidence of adverse effect was observed. - forphenicinol ; small molecular BRM ; T and B cells; NK activity

Forphenicinol [L-2-(3-hydroxy-4-hydroxymethylphenyl) glycine, M.W. 197. 19] (Morishima et al. 1982) is a derivative of forphenicine, an inhibitor of chicken intestine alkaline phosphatase $\left(\mathrm{IC}_{50}: 0.03 \mu \mathrm{g} / \mathrm{ml}\right)$ discovered by Umezawa and

Received February 25, 1985 ; accepted for publication April 10, 1985.

* A part of this paper was presented at the 40th Annual Meetings of Japanese Cancer Association, Sapporo, 1981, and at the 13th International Cancer Congress, Seattle, 1982. 
his associates in the culture filtrates of Actinomycetes (Aoyagi et al. 1978; Yamamoto et al. 1978; Umezawa 1981). Forphenicinol which did not inhibit the enzyme $\left(\mathrm{IC}_{50}: 350 \mu \mathrm{g} / \mathrm{ml}\right)$ was found to enhance immune responses in mice (Ishizuka et al. 1982a) and exhibit the antitumor effect on murine transplantable tumors as well as a protective effect on Pseudomonas infections by oral administration (Ishizuka et al. 1982b). Forphenicinol was also shown to have extremely low toxicity in experimental animals (Ishizuka et al. 1982b).

Based on these findings, phase I studies have been carried out by the Japanese Forphenicinol Clinical Study Group since December, 1981. We aimed to find an optimal dose of the drug with respect to its effect(s) on the immunological parameters in patients with cancer and those with tuberculosis. The present paper describes the changes in the frequencies of peripheral $\mathrm{T}$ and $\mathrm{B}$ lymphocytes, $\mathrm{NK}$ activity, and the proliferative response to PHA after a single oral dose of forphenicinol.

\section{Materials and Methods}

Patients

Characteristics of a total of 55 patients (43 males and 12 females) are summarized in

TABLE 1. Characteristics of patients examined

\begin{tabular}{lccc}
\hline \multirow{2}{*}{$\begin{array}{c}\text { Diagnosis and } \\
\text { age range }\end{array}$} & \multicolumn{3}{c}{ Number of patients } \\
\cline { 2 - 4 } & Male & Female & Total \\
\hline Lung cancer & 29 & 6 & 35 \\
Adeno & 10 & 3 & 13 \\
Epidermoid & 9 & 0 & 9 \\
Small cell & 6 & 0 & 6 \\
Large cell & 1 & 0 & 1 \\
Adeno-Epid & 0 & 1 & 1 \\
Unclassified & 3 & 0 & 3 \\
Metastatic & 0 & 2 & 2 \\
Malignant thymoma & 1 & 0 & 1 \\
Tuberculosis & 10 & 3 & 13 \\
Miscellaneous* & 3 & 3 & 6 \\
\hline <49-year & 4 & 3 & 7 \\
50- to 59-year & 14 & 3 & 17 \\
60- to 69-year & 14 & 5 & 19 \\
70-year< & 11 & 1 & 12 \\
\hline Overall & 43 & 12 & 55 \\
\hline
\end{tabular}

* Each 1 of bronchiectasis, pneumonia, diabetes mellitus with esophageal varix, sarcoidosis, suspect of thymoma, and suspect of pulmonary tuberculosis. 
Table 1. Thirty-six patients with malignant diseases consisted of 35 lung cancer (29 males and 6 females) and 1 malignant thymoma. None of these patients (except 2 lung cancer cases) had received any prior chemotherapy. Clinical stages were III to IV in more than two-third of the present cases. Thirteen patients with pulmonary tuberculosis (10 males and 3 females) were all positive for $M$. tuberculosis, cavitary, and on chemotherapy. Six patients with miscellaneous diagnoses were also included (each 3 males and females, see legend of Table 1). Performance status of these patients was 0 to 2 with a few exception of 3. As for the age distribution, nearly two-third of the present cases were in a range from 50 - to 69-year, and the youngest was the age of 19 and the eldest was of 78.

Dosage schedules and parameter assays

Forphenicinol (10, 50, or $200 \mathrm{mg} /$ capsule) was prepared by Banyu Pharmaceutical Co. Ltd., Tokyo, and kindly provided by Dr. H. Umezawa and Dr. S. Oka, Institute of Microbial Chemistry, Tokyo. A single oral dose ranging from 10 to $600 \mathrm{mg}$ per body was given throughout the present study unless otherwise stated (see also Table 4).

The peripheral mononuclear cells (MNC) isolated from each subject before, 1,3 , and 8 days after the drug administration were subjected to the following parameter assays; 1 ) Frequencies of T and B cells, 2) NK activity, and 3) Proliferative response to PHA.

\section{Isolation of $M N C$}

MNC were freshly isolated from the heparinized venous blood by Ficoll-Hypaque density gradient centrifugation. Viability was never less than $98 \%$ as assessed by trypan blue dye exclusion.

\section{Rosette assay for $T$ and $B$ cells}

Frequencies of $\mathrm{T}$ and $\mathrm{B}$ cells were enumerated by the rosetting in microtest plate (Kondo et al. 1978). The indicator cells were purchased from Japan Immunoresearch Laboratories Co. Ltd., Takasaki.

${ }^{51} \mathrm{Cr}$-release assay for $\mathrm{NK}$ activity

K562 cells (4-day-culture, approximately $1 \times 10^{7} / \mathrm{ml}$ ) were labelled with $100 \mu \mathrm{Ci}^{51} \mathrm{Cr}$ $\left(\mathrm{Na}_{2}{ }^{51} \mathrm{CrO}_{4}\right.$ in saline, New England Nuclear Corp., Boston, Mass., U.S.A., Sp. act. $285 \mathrm{mCi}$ / $\mathrm{mg} \mathrm{Cr}$ ) according to the procedure described by Itoh et al. (1980). A 2- $\mu$ l-portion of the labelled target cell suspension $\left(2 \times 10^{4}\right)$ was mixed with $0.2 \mathrm{ml}$ of varying concentrations of effector MNC suspension in Linbro round-bottom microtiter plates in triplicate (Kay et al. 1979). The medium used was RPMI-1640 supplemented with $10 \%$ fetal calf serum (FCS, GIBCO, Grand Island, N.Y., U.S.A.) and $10 \mathrm{mM}$ N-2-hydroxyethylpiperazineN'2ethanesulfonic acid. After a 4 -hr-culture at $37^{\circ} \mathrm{C}$ in a $5 \% \mathrm{CO}_{2}$-humidified incubator with occasional rocking, the supernatants were collected by the Titertek automatic harvesting system (Flow Lab., Rockville, Md., U.S.A.), and counted in a Gamma Counting System (Packard Auto Gamma 500C). The percentages of cytotoxicity were calculated from the means of triplicate assay as $[(\mathrm{A}-\mathrm{B}) / \mathrm{T}] \times 100$, where $\mathrm{A}=$ counts per minute $(\mathrm{cpm})$ of test samples; $\mathrm{B}=\mathrm{cpm}$ of medium control ; and $\mathrm{T}=\mathrm{cpm}$ of the total amount of ${ }^{51} \mathrm{Cr}$ incorporated into the target cells.

\section{Proliferative response to $\mathrm{PHA}$}

Aliquots of $0.2 \mathrm{ml} \mathrm{MNC}\left(1 \times 10^{6} / \mathrm{ml}\right.$ of RPMI- $1640 / 20 \%$ heat-inactivated FCS $)$ were added to round-bottom microtiter plates. Each triplicate wells were added with $2 \mu \mathrm{l}$ of PHA-P (Difco Lab., Detroit, Mich., U.S.A., 1/100 dilution) or the medium. The plates were incubated at $37^{\circ} \mathrm{C}$ in $5 \% \mathrm{CO}_{2}$ for $72 \mathrm{hr}$, and pulsed for the last $24 \mathrm{hr}$ with $0.2 \mu \mathrm{Ci}$ thymidine6- $\left[{ }^{3} \mathrm{H}\right]$ (New England Nuclear, Boston, Mass., U.S.A., sp. act. $24.7 \mathrm{Ci} / \mathrm{mM}$ ). The cells were harvested with an automatic multiple cell harvester (Labo Mash, Labo Science Co. Ltd., Tokyo), and the radioactivity was counted in a liquid scintillation counter (Beckman 
LS-150). The results were expressed as stimulation index (S.I.).

\section{Results}

Initial levels of $T$ and $B$ cells and their changes after single dose of forphenicinol

The possible changes in the relative percentages of peripheral $\mathrm{T}$ and $\mathrm{B}$ lymphocytes after a single oral dose of forphenicinol ( 10 to $600 \mathrm{mg}$ per body) were examined in a total of 43 patients ( 25 cancer, 13 tuberculosis, and 5 others). Referring to the normal range reported for T cells $(81 \pm 5 \%)$ and B cells $(19 \pm 6 \%)$ (Kondo et al. 1978), the frequency of $\mathrm{T}$ cells less than $76 \%$ was referred to as 'low' while that of B cells exceeding $25 \%$ or less than $13 \%$ was designated as 'high' or 'low', respectively. Before administration of the drug, abnormal proportion of $\mathrm{T}$ and B cells was found in approximately one-half of the present patients as generally evidenced by 'low'-T and 'high'-B. And the effect of forphenicinol was most clearly observed in these cases. Thus, the relative proportion of $\mathrm{T}$ and $\mathrm{B}$ cells tended to normalize from the next day of the drug administration, the maximum response being found after 1 to 3 days in most cases. The effect of the drug usually disappeared 8 days after a single dose.

Table 2 summarizes the changes in $\mathrm{T}$ cells with reference to the initial levels. Of 25 patients with cancer, 12 had 'low' initial levels with the mean percentage of 68.0. After a single dose of forphenicinol (pooled results with 10 to $600 \mathrm{mg}$ ), the frequency of $\mathrm{T}$ cells increased significantly in 8 of 12 cases resulting in the mean percentage of $75.6(p<0.05)$. On the other hand, $\mathrm{T}$ cell levels were initially in a normal range in the rest of 13 cases $(81.5 \%)$, and no significant increase was observed after the drug administration $(83.2 \%)$. A similar change was also found in the patients with tuberculosis; the mean percentage of $\mathrm{T}$ cells increased from 63.1 to $78.5(p<0.05)$ in 7 of 13 cases, while the normal initial level $(81.0 \%)$ stayed unchanged in the rest of 6 cases $(80.4 \%)$.

As summarized in Table 3, B cells also tended to converge to a normal level. Thus, the mean percentage of B cells decreased from the 'high' initial level of 34.6 to 26.9 in 7 of 25 patients with cancer, and from 34.9 to 14.3 in 6 of 13 cases with tuberculosis $(p<0.025)$. On the other hand, it increased from the 'low' initial level of 9.9 to 17.6 in 6 cases with cancer $(p<0.05)$ and from 8.5 to 15.5 in 5 cases with tuberculosis $(p<0.05)$. However, no significant change was observed in the rest of patients with either cancer or tuberculosis whoes B cell levels were in a normal range before administration of the drug.

\section{Dose-related changes in $T$ and $B$ cells}

The possible dose-related effect of forphenicinol was analyzed by comparing the number of cases in which the above observed changes in the frequencies of $\mathrm{T}$ and/or B cells exceeded $10 \%$. As shown in Table 4, rate of the positive response was significantly different depending on the dosage of the drug, the highest incidence being found at 60 to $100 \mathrm{mg}$ ( $6 / 8$ for $\mathrm{T}$ cell, $7 / 7$ for B cell) compared to 
TABLE 2. T lymphocyte response to forphenicinol* with reference to the initial levels

\begin{tabular}{|c|c|c|c|c|c|c|c|}
\hline \multicolumn{3}{|c|}{ Patient group (No.) } & \multicolumn{2}{|c|}{$\mathrm{T}$ cell $(\%) \pm \mathrm{S} . \mathrm{D}}$. & \multirow[t]{2}{*}{$p$-value } & \multirow{2}{*}{$\begin{array}{l}\text { No. of } \\
\text { positive } \\
\text { response // } \\
\text { /Total }(\%)\end{array}$} & \multirow{2}{*}{$p$-value $\emptyset$} \\
\hline & & & Before & After $\ddagger$ & & & \\
\hline \multirow{2}{*}{$\begin{array}{c}\text { Cancer } \\
(25)\end{array}$} & Low-T $\dagger$ & $(12)$ & $68.0 \pm 8.8$ & $75.6 \pm 8.9$ & $<0.05$ & $8 / 12(66.7)$ & \multirow{2}{*}{$<0.05$} \\
\hline & Normal-T & $(13)$ & $81.5 \pm 3.6$ & $83.2 \pm 4.3$ & NS & $2 / 13(15.4)$ & \\
\hline \multirow{2}{*}{$\begin{array}{l}\text { Tuber- } \\
\text { culosis } \\
(13)\end{array}$} & Low-T $\dagger$ & $(7)$ & $63.1 \pm 7.6$ & $78.5 \pm 8.3$ & $<0.05$ & $6 / 7(85.7)$ & \multirow{2}{*}{ NS } \\
\hline & Normal-T & $(6)$ & $81.0 \pm 4.1$ & $80.4 \pm 6.3$ & $\mathrm{NS}$ & $2 / 6(33.3)$ & \\
\hline $\begin{array}{l}\ddagger \\
\S \\
/ / \\
\prod\end{array}$ & \multicolumn{7}{|c|}{$\begin{array}{l}\text { Single dose of } 10 \text { to } 600 \mathrm{mg} / \text { body was administered orally on day } 0 \text {. } \\
\text { Initial T cell level below } 76 \% \text {, referring to the normal range reported } \\
(81 \pm 5 \%) \text {. } \\
\text { The highest value obtained on day } 1,3 \text {, or } 8 \text {. } \\
\text { Difference between 'before' and 'after' as evaluated by Student's } t \text {-test. } \\
\text { T cell increase exceeding } 5 \% \text { on day } 1,3 \text {, or } 8 \text {. } \\
\text { Difference between 'low' and 'normal' ( } \chi^{2} \text {-test). }\end{array}$} \\
\hline
\end{tabular}

TABLE 3. B lymphocyte response to forphenicinol* with reference to the initial levels

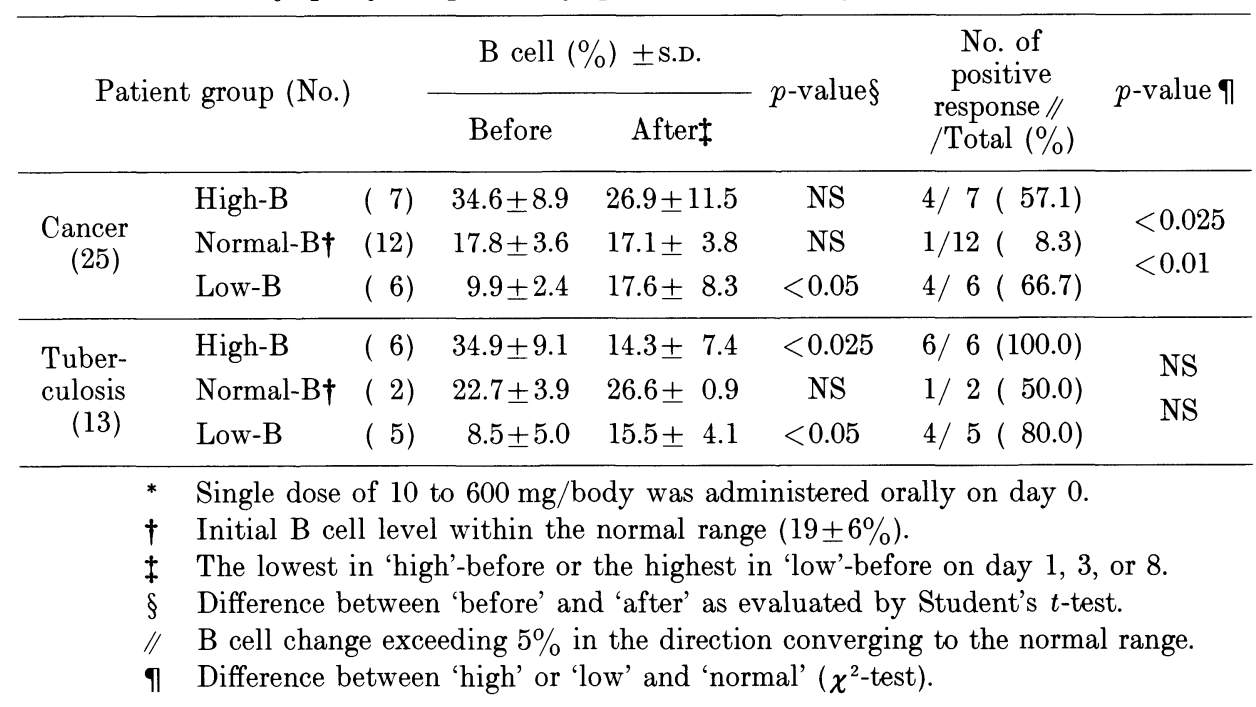

either 200 to $600 \mathrm{mg}(0 / 7$ for $\mathrm{T}$ cell, $1 / 3$ for B cell) or 10 to $40 \mathrm{mg}(2 / 7$ for $\mathrm{T}$ cell, $2 / 3$ for B cell) An optimal dose of forphenicinol in restoring the normal proportion of the peripheral $\mathrm{T}$ and $\mathrm{B}$ lymphocytes was suggested to be around 60 to 100 mg per body, as far as a single dose was concerned.

\section{Changes in NK activity}

The relative NK activities of the peripheral MNC before and after a single dose of forphenicinol were determined in 11 patients by measuring the lysis of ${ }^{51} \mathrm{Cr}$-labeled K562. Five males of lung cancer ( 46 to 65 years of age) and 1 female 
Table 4. Dose-related changes in $T$ and $B$ lymphocytes

\begin{tabular}{|c|c|c|c|c|}
\hline $\begin{array}{c}\text { Forphenicinol } \\
\text { dosage } \\
(\mathrm{mg} / \text { body })^{*}\end{array}$ & \multicolumn{2}{|c|}{$\begin{array}{l}\text { No. of T cell } \\
\text { increase } \dagger / \text { No. } \\
\text { of 'low'-T } \ddagger(\%)\end{array}$} & \multicolumn{2}{|c|}{$\begin{array}{c}\text { No. of B cell } \\
\text { decrease } \dagger / \text { No. } \\
\text { of 'high'-B } \S(\%)\end{array}$} \\
\hline 10 & $0 / 2$ & \multirow{3}{*}{$2 / 7$} & $1 / 1$ & \multirow{3}{*}{$2 / 3$} \\
\hline 20 & $1 / 2$ & & $1 / 1$ & \\
\hline 40 & $1 / 3$ & & $0 / 1$ & \\
\hline 60 & $2 / 2$ & \multirow{2}{*}{$6 / 8(75) / /$} & $1 / 1$ & \multirow{2}{*}{$7 / 7(100)$} \\
\hline 100 & $4 / 6$ & & $6 / 6$ & \\
\hline 200 & $0 / 2$ & \multirow{3}{*}{$0 / 7$} & $0 / 1$ & \multirow{3}{*}{$1 / 3$} \\
\hline 400 & $0 / 3$ & & $1 / 2$ & \\
\hline 600 & $0 / 2$ & & 0 & \\
\hline $\begin{array}{ll}* & \text { A sir } \\
\dagger & \text { Chan } \\
\ddagger & \text { Norn } \\
\S & \text { Norn } \\
/ / & p<0\end{array}$ & $\begin{array}{l}\text { se was } \\
\text { ceedin } \\
\text { ge }: 8 \\
\text { ge : } 1 \\
\text {-test }\end{array}$ & $\begin{array}{l}\text { given orall } \\
\text { g } 10 \% \\
1 \pm 5 \% \\
9 \pm 6 \% \\
\text { against the }\end{array}$ & n day 0 & range). \\
\hline
\end{tabular}

of pneumonia (57 years of age) were administered with a $60 \mathrm{mg}$-dose, while 2 males of lung cancer ( 71 and 72 years of age) and 3 males of pulmonary tuberculosis (57 to 59 years of age) received a $100 \mathrm{mg}$-dose.

Fig. 1 illustrates the individual change in the lytic activity at various effector to target rations. The results obtained with a $60 \mathrm{mg}$-dose were variable. Thus, the cytotoxicity increased in 2 cancer cases on day 3 (Cases 32,34) and in 1 case on day 8 (Case 33). On the other hand, it decreased in 1 pneumonia (Case 30) who had a relatively high initial level. The low initial levels in 2 cancer cases $(29,31)$ stayed unchanged. With a $100 \mathrm{mg}$-dose, NK activity was suppressed in all 5 cases examined.

Table 5 summarizes the changes in NK activity after forphenicinol administration. In general, it tended to decrease at $100 \mathrm{mg}(p<0.025)$, while no significant change was observed at $60 \mathrm{mg}$. There was also a considerable fluctuation from one individual to another in the initial levels as well as in the changes thereafter.

\section{Negative effect on the proliferative response}

The proliferative response of the peripheral MNC was measured in 9 patients with lung cancer (54- to 78-year-old males) before and after forphenicinol administration; a single dose of $60 \mathrm{mg}$ in 5 cases, $200 \mathrm{mg}$ in 1 case, and 7 daily doses of $30 \mathrm{mg}$ in 3 cases. The results are given in Fig. 2 . The initial levels of S.I. were significantly lower in these patients compared to those of 13 healthy volunteers (10 males and 3 females of 24 to 50 years of age). The changes after the drug administration were variable within the low initial range. Namely, S.I. tended to 


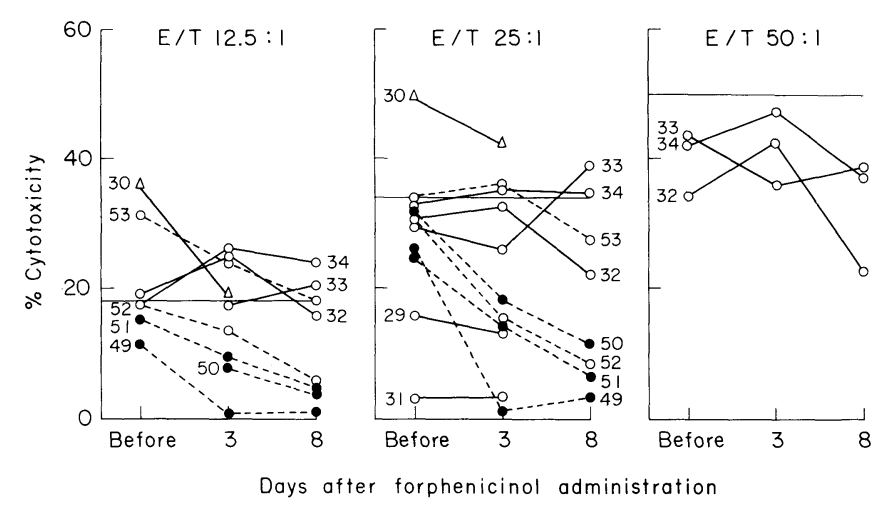

Fig. 1. Changes in NK activity after forphenicinol administration.

Each point represents the mean of triplicate cultures. Case No. is given aside each line. Holizontal lines show the mean value of healthy volunteers at each $\mathrm{E} / \mathrm{T}$ ratio. Lung cancer $(O)$; tuberculosis $(\bullet)$; pneumo$\operatorname{nia}(\triangle) . \quad 60 \mathrm{mg} ; \cdots \cdot 100 \mathrm{mg}$

TABLE 5. Changes in NK activity after forphenicinol administration

\begin{tabular}{cccc}
\hline \multirow{2}{*}{$\begin{array}{c}\text { Forphenicinol } \\
\text { dosage } \\
(\mathrm{mg} / \text { body })^{*}\end{array}$} & \multicolumn{3}{c}{ \% Cytotoxicity (mean \pm s.D. $) \dagger$} \\
\cline { 2 - 4 } & Before & Day 3 & Day 8 \\
\hline $60 \times 1(\mathrm{n}=6)$ & $27.6 \pm 15.9$ & $25.9 \pm 14.8$ & $31.5 \pm 8.5$ \\
$100 \times 1(\mathrm{n}=5)$ & $29.8 \pm 3.9$ & $17.2 \pm 12.2 \ddagger$ & $11.4 \pm 9.1 \S$ \\
\hline
\end{tabular}

* Orally administered on day 0 .

$\dagger$ Lytic activity of the peripheral MNC against ${ }^{51} \mathrm{Cr}$-labeled K562 at

effector to target ratio of $25: 1$ (see also Materials and Methods).

$\ddagger p<0.025$ ( $\chi^{2}$-test against 'before').

$\S p<0.005$ ( $\chi^{2}$-test against 'before').

decrease in 4 cases $(1,4,27,28)$, while it increased in 3 cases $(2,3,22)$ and unchanged in 2 cases $(5,26)$.

\section{Discussion}

As a part of phase I study of forphenicinol, we investigated the changes in the immunological parameters after a single oral dose, in order to find an optimal dose in patients with cancer and those with tuberculosis. Forphenicinol was found to be effective in restoring the normal proportion of the peripheral $\mathrm{T}$ and $\mathrm{B}$ lymphocytes especially in those who had 'low'-T and 'high'-B before administration of the drug. With respect to this parameter, an optimal dose of forphenicinol was suggested to be in a range from 60 to $100 \mathrm{mg}$ per body. A comparable dose range has also been reported from other laboratories on the basis of similar parameter studies with 7 daily doses of the drug (Majima 1982; Terakado et al. 1983). No significant difference was found between cancer and tuberculosis, and 


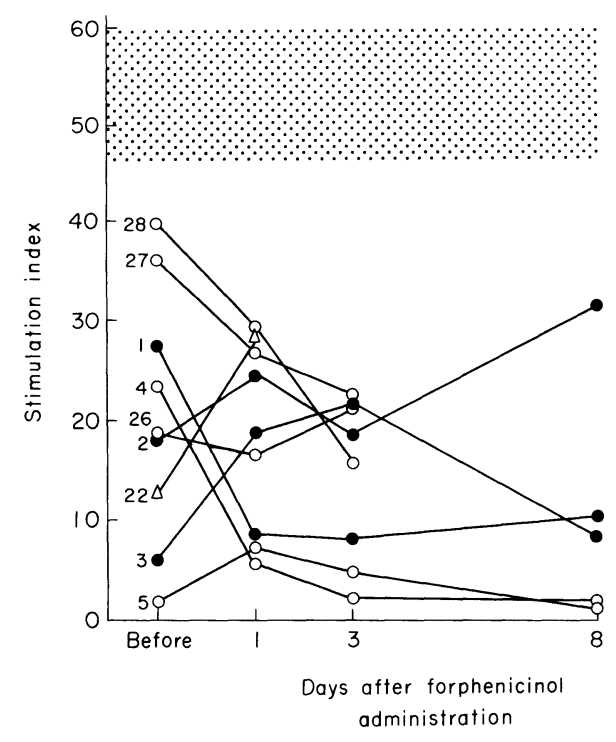

Fig. 2. Negative effect of forphenicinol on the proliferative response to PHA. Each point represents the mean of triplicate cultures. Case No. is given aside each line. Dotted zone represents the normal range determined in 13 healthy volunteers. $30 \mathrm{mg} \times 7(\bullet) ; 60 \mathrm{mg} \times 1(\mathrm{O}) ; 200 \mathrm{mg} \times 1(\triangle)$

a nonspecific nature was suggested for the immunorestorative effect of forphenicinol.

The effect of a single dose of the drug tended to disappear within 8 days in most cases, a peak response being found after 1 to 3 days. A peak level in the serum was reported to be attained dose responsively $2 \mathrm{hr}$ after the drug administration (Ishibashi et al. 1984). Neither any evidence of adverse effects nor any significant change in the lymphocyte counts was observed in the present trial with a single dose ranging from 10 to $600 \mathrm{mg}$ per body.

On the other hand, forphenicinol seemed to be rather inhibitory on the NK activity, while the effect on the lymphocyte proliferation was found to be diverse. The rosette assays paralleled with these functional assays indicated that the changes in $\mathrm{T}$ and $\mathrm{B}$ cells were observable independently of functional alterations. As for the possible suppressive effect of monocytes (Bordignon et al. 1982 ; Koren et al. 1981), we found no correlation between NK activity and monocyte content in the MNC preparations concerned. Negative effect on the lymphocyte proliferation was previously observed in experimental animals (Ishizuka et al. 1982a).

An immunorestorative effect of forphenicinol was demonstrated in the groups of patients with cancer and tuberculosis with respect to the relative proportion of the peripheral $\mathrm{T}$ and $\mathrm{B}$ cells. The possible effect of forphenicinol on the functional $\mathrm{T}$ cell subsets seems to be worthy of further study. 


\section{References}

1) Aoyagi, T., Yamamoto, T., Kojiri, K., Kojima, F., Hamada, M., Takeuchi, T. \& Umezawa, H. (1978) Forphenicine, an inhibitor of alkaline phosphatase produced by actinomycetes. J. Antibiot., 31, 244-246.

2) Bordignon, C., Villa, F., Allavena, P., Introna, M., Biondi, A., Avallone, R. \& Mantovani, A. (1982) Inhibition of natural killer activity by human bronchoalveolar macrophages. J. Immunol., 129, 587-591.

3) Ishibashi, T., Takamoto, M. \& Shinoda, A. (1984) Fundamental and clinical studies on forphenicinol, a small molecular immunomodulator. Jap. J. Antibiot., 37, 185197. (Japanese)

4) Ishizuka, M., Ishizeki, S., Masuda, T., Momose, A., Aoyagi, T., Takeuchi, T. \& Umezawa, H. (1982a) Studies on effect of forphenicinol on immune responses. $J$. Antibiot., 35, 1042-1048.

5) Ishizuka, M., Masuda, T., Kanbayashi, N., Watanabe, Y., Matsuzaki, M., Sawazaki, Y., Ohkura, A., Takeuchi, T. \& Umezawa, H. (1982b) Antitumor effect of forphenicinol, a low molecular weight immunomodifier, on murine transplantable tumors and microbial infections. J. Antibiot., 35, 1049-1054.

6) Itoh, K., Inoue, M., Kataoka, S. \& Kumagai, K. (1980) Differential effect of interferon on expression of IgG- and IgM-Fc receptors on human lymphocytes. J. Immunol., 124, 2589-2595.

7) Kay, H.D., Bonnard, G.D. \& Herberman, R.B. (1979) Evaluation of the role of IgG antibodies in human natural cell-mediated cytotoxicity against the myeloid cell line K562. J. Immunol., 122, 675-685.

8) Kondo, T., Watanabe, N. \& Tachibana, T. (1978) Rapid and simple assay in microtest plate for enumeration of human $\mathrm{T}$ and $\mathrm{B}$ lymphocyte population. Igakuno-Ayumi, 107, 312-314. (Japanese)

9) Koren, H.S., Anderson, S.J., Fischer, D.G., Copeland, C.S. \& Jensen, P.J. (1981) Regulation of human natural killing I. The role of monocytes, interferon, and prostaglandins. J. Immunol., 127, 2007-2013.

10) Majim, H. (1982) Changes in immunological parameters in patients administered with forphenicinol. Proc. 3rd Meeting Japanese Forphenicinol Clinical Study Group, 19-21. (Japanese)

11) Morishima, H., Yoshizawa, J., Ushijima, R., Takeuchi, T. \& Umezawa, H. (1982) Synthesis of forphenicinol and forphenicine. J. Antibiot., 35, 1500-1506.

12) Terakado, T., Saito, K., Tajima, K., Miyasato, H., Suzuki, T. \& Ikeda, S. (1983) A phase I study of forphenicinol, a new biological response modifier. Jap. J. Cancer Chemother., 10, 2309-2317. (Japanese)

13) Umezawa, H. (1981) Small molecular weight immunomodifiers produced by microorganisms: Their screening and discoveries, and the genetics of microbial secondary metabolites. In : Small Molecular Immunomodifiers of Microbial Origin-Fundamental and Clinical Studies of Bestatin, edited by H. Umezawa, Japan Scientific Society Press, Tokyo, pp. 1-16.

14) Yamamoto, T., Kojiri, K., Morishima, H., Naganawa, H., Aoyagi, T. \& Umezawa, H. (1978) The structure of forphenicine. J. Antibiot., 31, 483-484. 